DOI: $10.1515 /$ pts-2016-0007

APPLIED PHYSICS

\title{
TRIBOLOGICAL PROPERTIES OF PVD CARBON-COPPER COMPOSITE FILMS REINFORCED BY TITANIUM
}

\author{
J. Lungevics ${ }^{1}$, A. Leitans ${ }^{1}$, J. Rudzitis ${ }^{1}$, N. Bulahs ${ }^{1}$, P. Nazarovs ${ }^{2}$, V. Kovalenko ${ }^{2}$ \\ ${ }^{1}$ Institute of Mechanical Engineering, \\ Riga Technical University, \\ 6 Ezermalas Str., LV-1006, Riga, LATVIA \\ E-mail: mti@rtu.lv \\ ${ }^{2}$ LTD Naco Technologies \\ 24A-52 Ganibu dambis, LV-1005, Riga, LATVIA \\ E-mail: info@nacotechnologies.com
}

\begin{abstract}
Carbon-copper composite coatings reinforced with titanium were deposited using high power magnetron sputtering technique. Tribological and metrological tests were performed using Taylor Hobson Talysurf Intra 50 measuring equipment and CSM Instruments ball-on-disk type tribometer. Friction coefficient and wear rate were determined at $2 \mathrm{~N}, 4 \mathrm{~N}, 6 \mathrm{~N}$ loads. It was revealed that friction coefficient decreased at a higher Ti concentration, which was particularly expressed at bigger applied loads. However, wear volume values tended to increase in the beginning, till Ti concentration reached about $11 \%$, but then decreased, thus providing better nanocoating wear resistance.
\end{abstract}

Keywords: $3 D$ roughness, carbon-copper composite, magnetron sputtering, nanocoatings, solid lubricant, wear.

\section{INTRODUCTION}

Many enterprises that specialise in mechanical engineering are confronted with short life span of equipment and instruments that leads to high maintenance costs and low productivity. Friction causes the wear of machinery, accelerates decay of moving parts and decreases performance of instruments. Thus, decreasing the friction coefficient is necessary for low-cost, durable and energy-efficient machinery.

Physical vapour deposition magnetron sputtering technique [1], which does not affect the properties of the base material and biochemical functionality, is used for depositing tribological coatings for friction reduction and wear resistance. Such coatings have good adhesion and serve as a protective layer. Carbon-copper $(\mathrm{a}-\mathrm{C} / \mathrm{Cu})$ 
coatings are of particular interest [2]-[4]. Such coatings have a composite structure in which copper and graphite do not constitute carbide directly - copper nanoparticles are built in graphite matrix. a-C/Cu coatings are characterised with high mechanical and tribological quality index [5]; therefore, the present article researches these nanocoatings, aiming at obtaining the coefficient of surfaces with a low friction and, in compliance with it, the wear resistance.

\section{EXPERIMENTAL PROCEDURE}

$30 \mathrm{~mm}$ dia. $\mathrm{x} 3 \mathrm{~mm}$ chromium steel (100Cr6 after DIN 17230: 1980) plates were used as substrates. Prior to a deposition procedure, the ultrasonic cleaning of all samples using "Lotonaxe" degreasing bath was performed; then the water-alcohol mixture cleaning and drying with hot air were made.

Deposition equipment scheme is shown in Fig. 1. Base pressure of vacuum chamber is $1 * 10^{-3} \mathrm{~Pa}$. Substrates were fixed on a two-fold rotating table and its surface was activated in argon atmosphere using ion-beam gun at $500 \mathrm{~V}$ bias potential and heated to a temperature of $350 \pm 20{ }^{\circ} \mathrm{C}$.

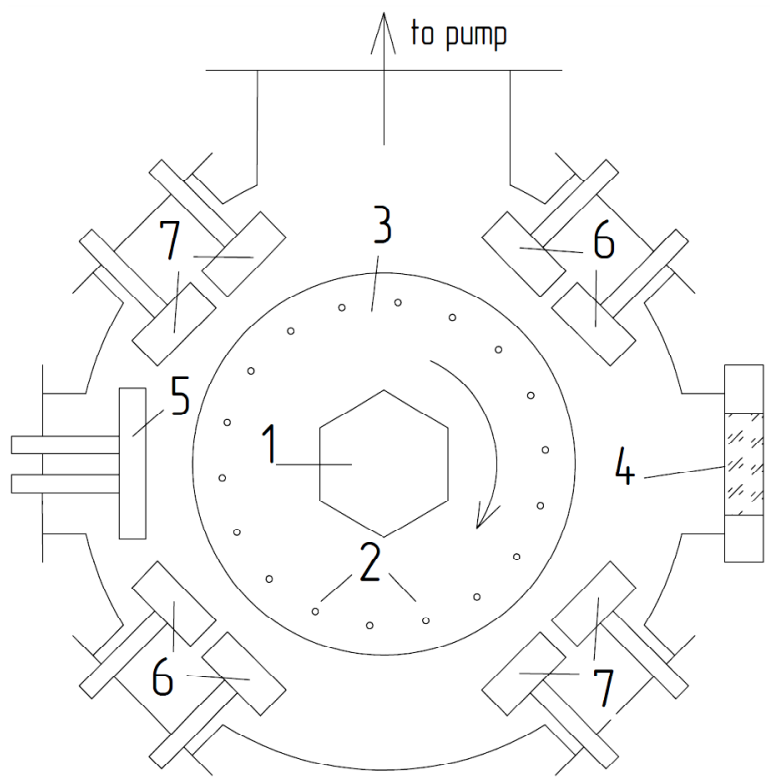

Fig. 1. Scheme of a vacuum sputtering system, 1 - heater, 2 - substrate holders, 3 - rotating table, 4 - view port, 5 - ion-beam gun, 6 - magnetrons with Ti targets, 7 - magnetrons with mosaic $\mathrm{Cu}-\mathrm{C}$ targets (or $\mathrm{Cu}$ targets).

a- $\mathrm{C} / \mathrm{Cu}$ nanocomposite films were deposited by high power DC magnetron sputtering process using high-performance industrial unit VU-SMA 600/4 [6]. Substrate-target distance of $100 \mathrm{~mm}$ and argon pressure pf $0.4 \mathrm{~Pa}$ were used during deposition. $\mathrm{Cu} / \mathrm{C}$ mosaic type target with a $14-44 \%$ carbon content supplied 7-40 at. $\%$ of carbon in the coatings. $-100 \mathrm{~V}$ bias voltage was provided for a deposition 
experiment. Power density on $\mathrm{Cu} / \mathrm{C} 70 \mathrm{~mm}$ dia. targets (see Fig. 2) reached $50 \mathrm{~W} /$ $\mathrm{cm}^{2}$, which ensured a deposition rate up to $0.10 \mu \mathrm{m} / \mathrm{min}$. Power density on Ti targets varied in the interval of $10-50 \mathrm{~W} / \mathrm{cm}^{2}$ that resulted in titanium content of 5.5-19 at. $\%$.

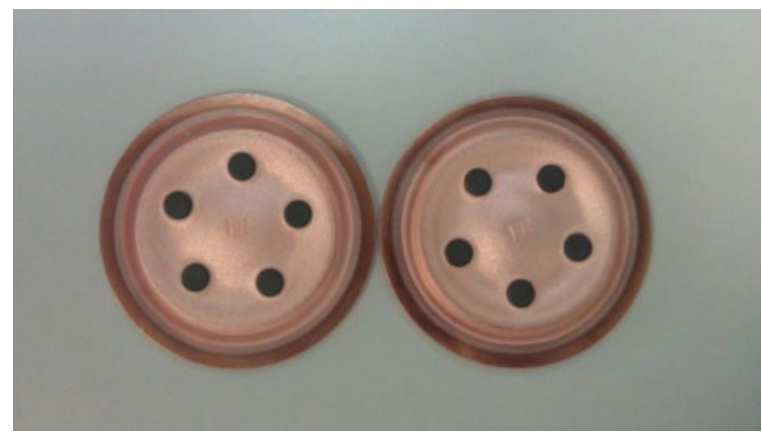

Fig. 2. $\mathrm{Cu} / \mathrm{C}$ target.

In all the experiments, the coating was made of several layers: the first one was a $300 \mathrm{~nm}$ titanium layer, which provided coating adhesion, and the others were $\mathrm{Cu}-\mathrm{C}$ and titanium nanolayers. Deposition experiment regimes are listed in Table 1.

Table 1

$\mathrm{Cu} / \mathrm{C}$ Coating Deposition Regimes

\begin{tabular}{|l|l|c|c|c|}
\hline No. & Coating type & Thickness, $\mu \mathrm{m}$ & $\mathrm{P}(\mathrm{Ti}) / \mathrm{P}($ Total $), \%$ & $\mathrm{P}($ Total $), \mathrm{kW}$ \\
\hline 1 & $\mathrm{CuC}$ & 5.3 & 0 & 9.2 \\
\hline 2 & $\mathrm{CuC}$ & 8.5 & 0 & 9.2 \\
\hline 3 & $\mathrm{CuC}+\mathrm{Ti}$ & 10.3 & 14.8 & 10.8 \\
\hline 4 & $\mathrm{CuC}+\mathrm{Ti}$ & 8.6 & 30.3 & 13.2 \\
\hline 5 & $\mathrm{CuC}+\mathrm{Ti}$ & 8.5 & 41.0 & 15.6 \\
\hline 6 & $\mathrm{CuC}+\mathrm{Ti}$ & 6.8 & 49.5 & 18.2 \\
\hline
\end{tabular}

After the deposition experiment, Ti percentage of the coating was determined. Atomic emission spectrometer Leco GDS850A was used for this purpose [7]. The samples were analysed with glow discharge excitation in direct current mode, with 4 $\mathrm{mm}$ anode at a constant voltage and current stabilisation $(900 \mathrm{~V}, 30 \mathrm{~mA})$. Ti percentage of the observed samples can be seen in Table 2 .

Table 2

Ti Percentage of the Nanocoating

\begin{tabular}{|l|c|}
\hline Sample No. & Ti, at.\% \\
\hline 1,2 & $0 \%$ \\
\hline 3 & $5.5 \%$ \\
\hline 4 & $11 \%$ \\
\hline 5 & $15 \%$ \\
\hline 6 & $19 \%$ \\
\hline
\end{tabular}




\section{EXPERIMENTAL PART}

In order to evaluate the qualities of nanocoating surface use, it was important to look at coating surface microtopography and to specify $3 \mathrm{D}$ roughness parameters, as well as to conduct tribological experiments for determining friction coefficient and wear intensity.

Coating surface 3D microtopography measurements were made using Taylor Hobson Form Talysurf Intra 50 profilometer. Measurement settings are shown in Table 3.

Table 3

3D Microtopography Measurement Settings

\begin{tabular}{|l|c|}
\hline Stylus & Standard Stylus Arm 112/2009 \\
\hline Number of points $(Y)$ & 500 \\
\hline Data length $(\mathrm{Y})$ & $2 \mathrm{~mm}$ \\
\hline Number of points $(\mathrm{X})$ & 500 \\
\hline Data length $(\mathrm{X})$ & $2 \mathrm{~mm}$ \\
\hline Measurement speed & $0.5 \mathrm{~mm} / \mathrm{s}$ \\
\hline
\end{tabular}

All microtopography images (Fig. 3) were processed in Talymap Expert software according to the following algorithm: 1) Form error was removed to obtain horizontal surface - primary surface; 2) Roughness was filtered from primary surface, using Gaussian filter and cut-off according to ISO 25178-2:2012 recommendations; 3) 3D roughness parameter Sa was calculated.

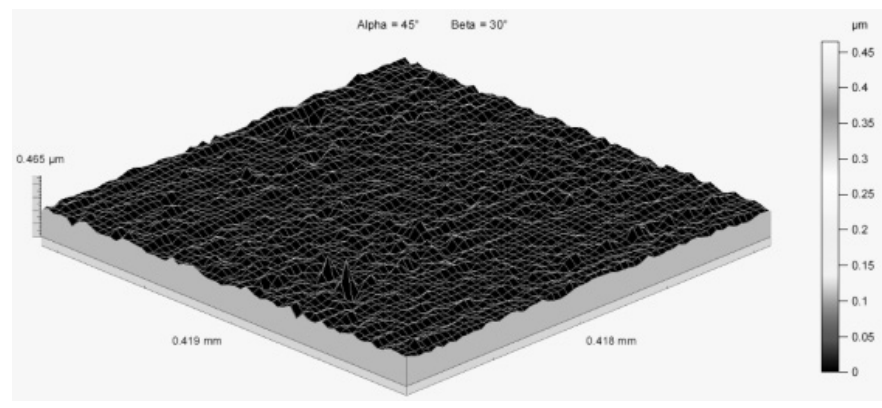

a

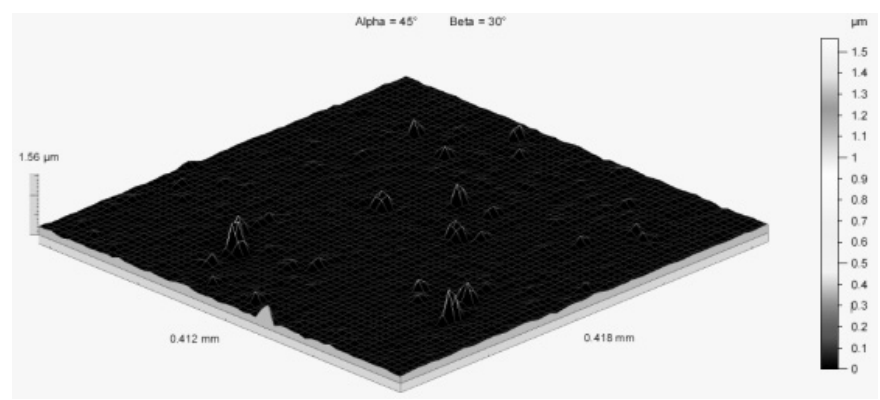

b

Fig. 3. Surface roughness of samples No.1 and No.5 after filtering. 
Tribological experiments were performed on a CSM Instruments ball-on-disk type tribometer. Experiment settings are shown in Table 4.

Table 4

Tribological Experiment Settings

\begin{tabular}{|l|c|}
\hline Ball material and size & $100 \mathrm{Cr} 6, \varnothing=6 \mathrm{~mm}$ \\
\hline Applied load, $\mathrm{F}$ & $2,4,6 \mathrm{~N}$ \\
\hline Linear motion speed, $\mathrm{v}$ & $0.05 \mathrm{~m} / \mathrm{s}$ \\
\hline Sample rotation cycles, $\mathrm{n}$ & 1500 cycles \\
\hline Tribotrack radius, $\mathrm{R}$ & $3.0 ; 5.5 \mathrm{~mm}$ \\
\hline Environment & Ambient air, dry friction \\
\hline
\end{tabular}

The experiments with $2 \mathrm{~N}$ and $6 \mathrm{~N}$ load were carried out with tribotrack radius (R) $3.0 \mathrm{~mm}$, but for $4 \mathrm{~N}$ - with $5.5 \mathrm{~mm}$ radius, because of the limited sample surface area (see Fig. 4).

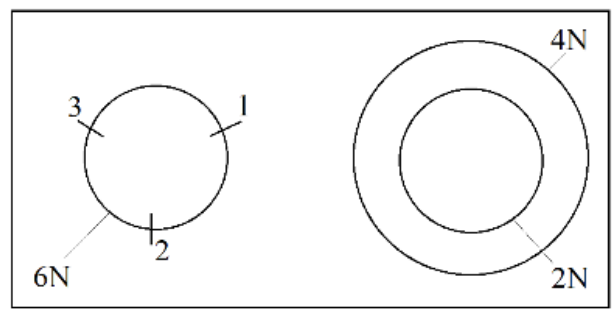

Fig. 4. Measurement location on the sample surface: $2 \mathrm{~N}, 4 \mathrm{~N}, 6 \mathrm{~N}$ - tribotracks; $1,2,3-$ cross-sectional area (A) measurement positions.

Friction coefficient $(C O F)$ was obtained as an average value from measurement, but tribotrack volume $\left(W_{v}, \mathrm{~mm}^{3}\right)$ and wear rate $\left(W_{r}, \mathrm{~mm}^{3} / \mathrm{N} \cdot \mathrm{m}\right)$ were calculated from tribotrack cross-sectional area $\left(A, \mu m^{2}\right)$ measurement (see Fig. 5).

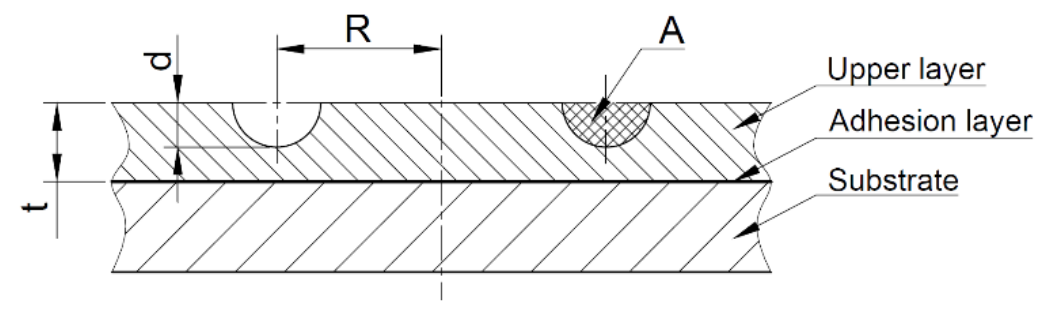

Fig. 5. Schematic image of sample cross-section after measurement

A - tribotrack cross-section area $\left(\mu \mathrm{m}^{2}\right) ; \mathrm{R}$ - tribotrack radius $(\mathrm{mm}) ; \mathrm{t}$ - coating thickness $(\mu \mathrm{m}) ; \mathrm{d}-$ tribotrack depth $(\mu \mathrm{m})$.

Cross-sectional area was measured using Taylor Hobson Surtronic 25 profilometer with standard pick up 112/1502, and values were calculated with Talymap Gold 4.1 software built-in function Surface of a Hole/Peak. Final cross-sectional area result was calculated as an average from three independent measurements (angle between measurements $\sim 120^{\circ}$ ), see Fig. 4. Tribotrack wear volume in $1 \mathrm{~mm}$ distance was calculated using the following equation: 


$$
W_{v}=A \cdot l_{1 m m}
$$

where $A$ - tribotrack cross-sectional area, $\mathrm{mm}^{2}$;

$l_{l m m}-1 \mathrm{~mm}$ distance of tribotrack, $\mathrm{mm}$.

The distance of $1 \mathrm{~mm}$ for tribotrack wear volume calculations was chosen in order to compare material volume loss intensity for tribotracks with different radius (R). Total tribotrack wear volume can be calculated by multiplying $W_{v}$ by track circumference length.

Wear rate was calculated using the following equation [10]:

$$
W_{r}=\frac{W_{v}}{F \cdot l}
$$

where $W_{v}$ - tribotrack volume, $\mathrm{mm}^{3}$;

$F$ - load on ball, N;

$l$ - total wear experiment distance, $\mathrm{m}$.

\section{RESULTS AND DISCUSSION}

Surface 3D microtopography measurements were accomplished for all 6 samples in order to see how coating affects substrate roughness. From the acquired 3D roughness images and calculated parameters, the authors conclude that all coatings form isotropic surface texture, which is rougher than the one of substrate (arithmetic mean of the deviations from the mean plane for substrate $-S_{a}=9.04 \mathrm{~nm}$ ), on which coating is deposited (see Table 5). This fact can be explained by copper $(\mathrm{Cu})$ tendency of forming peaky structure during the deposition process that increases the average value of surface roughness. It was also concluded that coatings with titanium (Ti) component show a tendency of having smoother surface than those without it. This can be explained by the fact that Ti particles replace $\mathrm{Cu}$ particles, thereby reducing $\mathrm{Cu}$ peak forming opportunity.

Tribological experiments with $F=2 \mathrm{~N}, \mathrm{~V}=0.05 \mathrm{~m} / \mathrm{s}, \mathrm{n}=1500$ cycles, $\mathrm{R}=3.0 \mathrm{~mm}$ were conducted. The obtained experiment data are summarised in Table 5.

Table 5

Experimental Measurement Data with 2N Applied Force

\begin{tabular}{|l|c|c|c|c|c|c|c|c|}
\hline Sample & Ti, at., $\%$ & $\mathrm{Sa}, \mathrm{nm}$ & $\mathrm{t}, \mu \mathrm{m}$ & $\mathrm{d}, \mu \mathrm{m}$ & $\mathrm{A}, \mu \mathrm{m}^{2}$ & $\mathrm{Wv}, \mu \mathrm{m}^{3}$ & $\mathrm{Wr}, \mathrm{mm}^{3} /(\mathrm{N} \cdot \mathrm{m})$ & $\mathrm{COF}$ \\
\hline 1 & 0 & 9.64 & 5.30 & 0.8 & 52.8 & $5.28 \mathrm{E}-05$ & $1.76 \mathrm{E}-05$ & 0.189 \\
\hline 2 & 0 & 13.60 & 8.50 & 0.91 & 40.20 & $4.02 \mathrm{E}-05$ & $1.34 \mathrm{E}-05$ & 0.187 \\
\hline 3 & 5.5 & 10.50 & 10.30 & 0.43 & 15.77 & $1.58 \mathrm{E}-05$ & $5.26 \mathrm{E}-06$ & 0.229 \\
\hline 4 & 11 & 9.90 & 8.60 & 0.79 & 48.43 & $4.84 \mathrm{E}-05$ & $1.61 \mathrm{E}-05$ & 0.256 \\
\hline 5 & 15 & 9.12 & 8.50 & 0.23 & 8.97 & $8.97 \mathrm{E}-06$ & $2.99 \mathrm{E}-06$ & 0.189 \\
\hline 6 & 19 & 10.20 & 6.80 & 0.31 & 17.57 & $1.76 \mathrm{E}-05$ & $5.86 \mathrm{E}-06$ & 0.226 \\
\hline
\end{tabular}


Soft a-C/Cu coatings (samples No. 1 and 2 ) were analysed by comparing their parameters $t$ and $d$ (see Fig. 5), and it was found that coating of such soft a-C/Cu films was not valid for practical applications because of very low wear resistance, while reinforced coatings (samples No. 3 to 6) showed a noticeable increase in wear resistance, whereas $C O F$ increase was relatively small. In order to get more detailed information on the Ti influence on coating tribological parameters, the second part of experiment was performed for all reinforced coatings (samples No. 3 to 6) and also for the best one of soft a-C/Cu coatings (sample No. 2). In additional experiments, two differently applied loads $(4 \mathrm{~N}, 6 \mathrm{~N})$ were used in order to see how Ti concentration influences coating tribological parameters at different contact pressures. The obtained data are shown in Table 6 .

Table 6

Experimental Measurement Data with 4N and 6N Applied Force

\begin{tabular}{|l|c|c|c|c|c|c|c|c|c|}
\hline \multirow{2}{*}{ Sample } & \multirow{2}{*}{ Ti, at. $\%$} & \multicolumn{2}{|c|}{$\mathrm{COF}$} & \multicolumn{2}{c|}{$\mathrm{d}, \mu \mathrm{m}$} & \multicolumn{2}{c|}{$\mathrm{Wv}, \mu \mathrm{m}^{3}$} & \multicolumn{2}{c|}{$\mathrm{Wr}, \mathrm{mm}^{3} /(\mathrm{N} \cdot \mathrm{m})$} \\
\cline { 3 - 10 } & & $4 \mathrm{~N}$ & $6 \mathrm{~N}$ & $4 \mathrm{~N}$ & $6 \mathrm{~N}$ & $4 \mathrm{~N}$ & $6 \mathrm{~N}$ & $4 \mathrm{~N}$ & $6 \mathrm{~N}$ \\
\hline 2 & 0 & 0.179 & 0.167 & 0.74 & 2.23 & $3.53 \mathrm{E}-05$ & $1.23 \mathrm{E}-04$ & $5.88 \mathrm{E}-06$ & $1.37 \mathrm{E}-05$ \\
\hline 3 & 5.5 & 0.243 & 0.258 & 1.54 & 2.14 & $1.02 \mathrm{E}-04$ & $1.79 \mathrm{E}-04$ & $1.70 \mathrm{E}-05$ & $1.90 \mathrm{E}-05$ \\
\hline 4 & 11 & 0.267 & 0.267 & 1.14 & 1.24 & $6.85 \mathrm{E}-05$ & $1.05 \mathrm{E}-04$ & $1.14 \mathrm{E}-05$ & $1.16 \mathrm{E}-05$ \\
\hline 5 & 15 & 0.207 & 0.225 & 0.96 & 1.67 & $2.56 \mathrm{E}-05$ & $5.11 \mathrm{E}-05$ & $4.27 \mathrm{E}-06$ & $5.68 \mathrm{E}-06$ \\
\hline 6 & 19 & 0.242 & 0.210 & 0.50 & 0.72 & $3.90 \mathrm{E}-05$ & $4.37 \mathrm{E}-05$ & $6.50 \mathrm{E}-06$ & $4.86 \mathrm{E}-06$ \\
\hline
\end{tabular}

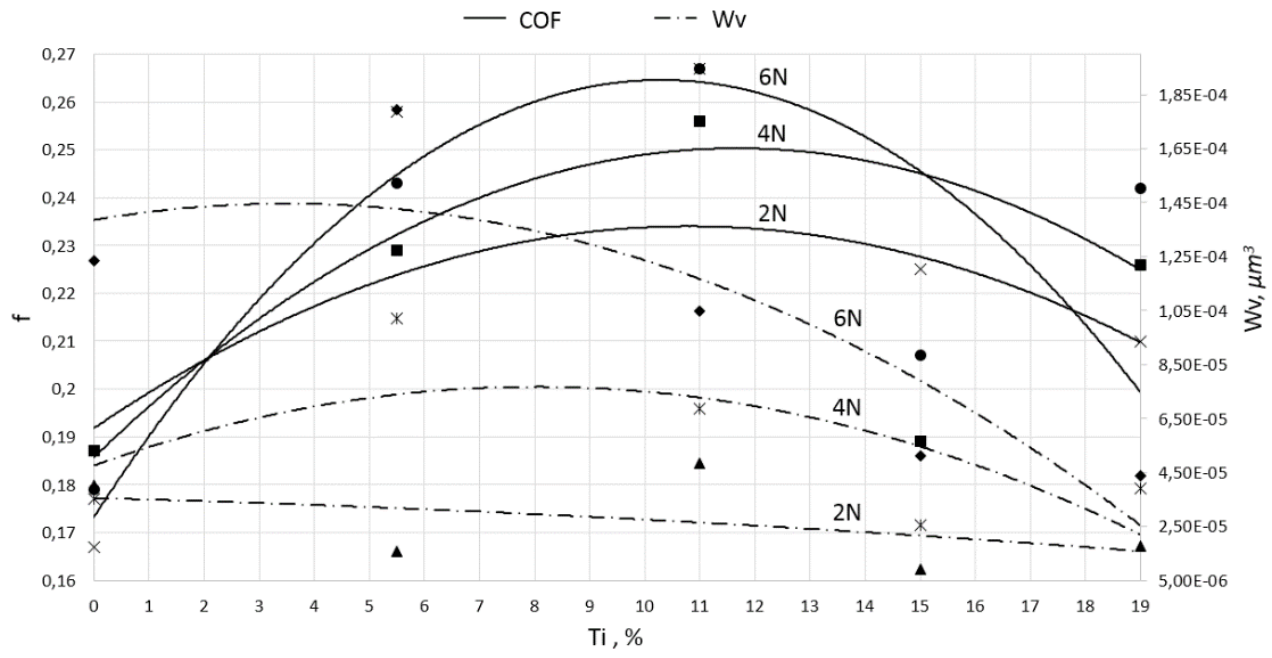

Fig. 6. Ti concentration influence on tribotrack wear volume (Wv) and coefficient of friction (COF).

Figure 6 shows that $C O F$ values tend to increase until Ti concentration reaches $\sim 11$ at. $\%$, and then decreases. It can be seen that $C O F$ overall values tend to be bigger if the applied load is increased; it can be explained by the fact that a bigger applied load tends to penetrate tribometer ball deeper into the coating, thus resulting in greater surface microcutting. Coating wear volume curves tend to copy $C O F$ curves, but after Ti concentration reaches $\sim 11$ at. $\%$, wear resistance increases rapidly, especially if a greater applied load is used, thus proving that coating reinforcing 
with Ti can significantly improve their overall tribological parameters. Experimental data show that the best tribological parameters are shown by sample No. 5 that has Ti concentration of $15 \%$.

\section{CONCLUSIONS}

In the present research, it has been stated that at the a-C/Cu coating deposition the surface properties are different, which is linked to the composition of nanocoating. When depositing $\mathrm{Ti}$ adhesive layer and then $\mathrm{Cu}-\mathrm{C}$ layer at different deposition modes, the values of coating wear resistance and the coefficient of friction change. After adding titanium to the a-C/Cu layer and varying its percentage composition, it can be concluded that the coefficient of friction increases at Ti concentration raising to $11 \%$, but wear volume values do not alter significantly. The coefficient of friction and wear volume decrease after further rise in Ti concentration. Consequently, it can be seen that the optimal coating wear resistance is at $11 \%$ Ti concentration.

\section{ACKNOWLEDGEMENTS}

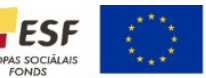

IEGULDIJUMS TAVĀ NĀKOTNEE
The research has been supported by the European Regional Development Fund within the project No. 2014/0011/2DP/2.1.1.1.0/13/ APIA/VIAA/005.

\section{REFERENCES}

1. Safi, I. (2000). Recent aspects concerning DC reactive magnetron sputtering of thin films. Surface \& Coatings Technology, 127 (2-3), 203-219.

2. Berman, D., Erdemir, A., and Sumant, V. A. (2013). Few layer graphene to reduce wear and friction on sliding steel surfaces. Elsevier, Carbon 54, 454-459.

3. Chan, Y. H., Huang, C. F., Ou, K. L., and Peng, P. W. (2011). Mechanical properties and antibacterial activity of copper doped diamond-like carbon films. Surface \& Coatings Technology. 206 (6), 1037-1040.

4. Cabioc'h, T., Naudon, A., Jaouen, M., Thiaudiére, D., and Babonneau, D. (1999). Cosputtering $\mathrm{C}-\mathrm{Cu}$ thin film synthesis: Microstructural study of copper precipitates encapsulated into a carbon matrix. Philosophical Magazine Part B, 79 (3), 501-516.

5. Musil, J., Louda, M., Soukup, Z., and Kubásek, M. (2008). Relationship between mechanical properties and coefficient of friction of sputtered a-C/Cu composite thin films. Diamond \& Related Materials, 17 (11), 1905-1911.

6. Mitin, V., Sharipov, E., and Mitin, A. (2006). High deposition rate magnetrons - innovative coating technology: Key elements and advantages. Surface Engineering, 22 (1), $1-6$.

7. Fernández, B., Pereiro, R., Sanz-Medel, A. (2010). Glow discharge analysis of nanostructured materials and nanolayers. Analytica Chimica Acta, 679 (1-2), 7-16. 


\title{
AR TITĀNU PASTIPRINĀTU PVD VARA-OGLEKLA KOMPOZĪTU PĀRKLĀJUMU TRIBOLOG̣ISKĀS İPAŠİBAS
}

\author{
J. Lungevics, A. Leitāns, J. Rudzītis, \\ N. Bulahs, P. Nazarovs, V. Koval̨enko
}

Kopsavilkums

Dotajā rakstā apskatīta dažādu pārklājumu ietekme, kas palielina virsmu nodilumizturību. Rakstā tika analizēti seši a-C/Cu nanopārklājumi, kuri atšķiras ar Ti koncentrāciju. Pētāmie paraugi tika pakḷauti metrologiiskām un tribologiskām pārbaudēm; Tika nomērīti virsmas raupjuma parametri ar mēriekārtu Taylor Hobson Talysurf Intra 50 un berzes koeficients ar CSM Instruments ball-on-disk type tribometer, un papildus aprēḳināti dilšanas intensitāte un dilušās zonas šḳērsgriezuma laukums. Pārbaudes eksperimentu laikā tika noteikts raupjuma parametrs Sa un berzes koeficients pie trim dažādām slodzēm: $2 \mathrm{~N}, 4 \mathrm{~N}, 6 \mathrm{~N}$. Iegūts, ka pie lielākas Ti koncentrācijas berzes koeficients samazinās, it īpaši tas ir izteicams pie lielākām slodzēm, savukārt dilšanas intensitātes vērtībām ir tendence no sākuma palielināties, pieaugot Ti koncentrācijai līdz aptuveni $11 \%$, bet pēc tām samazināties, nodrošinot tādā veidā labāku nanopārklājuma dilumizturību.

13.07.2015. 